\title{
Re-evaluation of Shallow Floodplain Aquifers Groundwater Potentials and Storage of Sokoto Basin, Northwestern Nigeria
}

\author{
Hamidu H. ${ }^{1,{ }^{*}}$, Lawal M. ${ }^{1}$, Abdulganiyu Y. ${ }^{2}$, Kwaya M. Y. ${ }^{1}$, Grema H. M. ${ }^{1}$, Ibrahim H.A. ${ }^{1}$, Kitha M. ${ }^{1}$, Yelwa N.A. ${ }^{1}$ \\ ${ }^{1}$ Department of Geology Faculty of Sciences, Usmanu Danfodiyo University, Sokoto, Nigeria \\ ${ }^{2}$ Department of Geology Faculty of Science Federal University Birnin Kebbi, Nigeria \\ *Corresponding author: hassanhamidu@yahoo.com
}

\begin{abstract}
Floodplains of Sokoto Basin with covering about 280,000 hectares of land was assessed for its shallow groundwater potentials. Data on pumping test of tube wells, logs and drilled tube wells were utilized for this study. Storativity was determined from known lithology of tube wells. Results of this study gives the ranges and averages of Hydraulic parameters for the shallow alluvial aquifers of hydraulic conductivity, transmissivity, specific capacity and storativity to be $6.66-1316 \mathrm{~m} /$ day and $214,044 \mathrm{~m} /$ day, $40-3950 \mathrm{~m}^{2} /$ day and $799.5 \mathrm{~m}^{2} /$ day, $12.25-5763.6$ $\mathrm{m}^{3} /$ day and $1,031 \mathrm{~m}^{3} /$ day and $1 \times 10^{-5}-6 \times 10^{-3}$ and $5 \times 10^{-4}$ respectively, While the Yields range of $0.3-71 / \mathrm{s}$ was obtained with $90 \%$ of tube wells evaluated having yields of $2.21 / \mathrm{s}$ and above. Lithologic Aquiferous units vary from medium sands, sands, coarse sands to gravel with thickness range of between 0.3 to $15 \mathrm{~m}$. Computed hydraulic conductivity indicates the aquifer materials to be gravels and alluvial sands of high permeability. Specific capacity values indicated the wells to be of high productivity when compared with standard values, Transmissivity average revealed the area to be of high groundwater transmission potentials. Overall assessment of the yields of tube wells studied indicated that $90 \%$ of the wells have yields that are above the minimum required for irrigation; the low average drawdown of $0.41 \mathrm{~m}$ recorded is an indication that the aquifers have high efficiency and high performance as regards storage and transmission of water. Recharge of the alluvial aquifers is mainly through surface river flow and precipitation, climate change have recently threaten the recharge potential s owing to the drying up of some of these streams and rivers at the peak of dry season as well reduction in rainfall. Statistical analysis has shown a good linear relationship between Specific capacity with yield, Transmissivity and hydraulic conductivity while Transmissivity is linearly related with yield and Conductivity. Generally the study revealed that the Sokoto basin Fadama land to be of high groundwater potentials, with storage coefficient values of confined and high yielding aquifers with capabilities of sustaining withdrawals for long period without recharge from external sources. Standard procedures are highly recommended to reduce or avoid the case of drilling abortive or low yielding wells.
\end{abstract}

Keywords: floodplains, alluvial aquifers, hydraulic characteristics, storativity, confined aquifer, Nigeria

Cite This Article: Hamidu H., Lawal M., Abdulganiyu Y., Kwaya M. Y., Grema H. M., Ibrahim H.A., Kitha M., and Yelwa N.A., "Re-evaluation of Shallow Floodplain Aquifers Groundwater Potentials and Storage of Sokoto Basin, Northwestern Nigeria." American Journal of Water Resources, vol. 5, no. 3 (2017): 72-84. doi: 10.12691/ajwr-5-3-3.

\section{Introduction}

Fadama is any low-lying land which is subject to seasonal flooding or waterlogging, including the floodplains of rivers and streams which has been inundated together with seasonal pools and depressions where land is moistened due to the rise in the water table, [1]. The total irrigation potentials of Nigeria is put at 2.0 million hectares, out of this figure the Fadama lands of northern Nigeria occupied about 0.94 million hectares, [2]. The area of study constitutes about 280,000 hectares of the Fadama land / Floodplains. Fadama and Floodplains Agriculture is being practiced throughout the dry season, Fadama land may be cultivated almost continuously, as rice can be grown in the wet season and followed by variety of dry season crops which rely on accumulated soil moisture or irrigation, [1]. Declining rainfall in the semi-arid northern Nigeria has put most floodplain located in this zone under pressure from several sources $[3,4]$. Due to the vulnerability of rain fed agriculture to decrease in rain $[5,6]$ this have being bringing added pressure and competition on the Fadama Alluvial aquifers. [7] pointed out that Fadama is important not only for irrigation potentials but also as a major source of groundwater for domestic consumption and livestock grazing. The traditional methods of irrigation involve lifting of water from perennial streams by Shadufs, or bucket on poles from shallow depressions and valley heads which dissect the uplands, this lead to only small percentage of the Fadama area to be used. [8] pointed out that groundwater 
is vital in Sokoto basin because of the limited amount of rainfall that falls for few months and as surface water sources get dried up at the peak of dry season before the on- set of the next wet season. Farmers and the inhabitants of the lowland areas have shifted their attention to the Fadama lowland areas shallow groundwater resources which has being utilized for irrigation and domestic uses since 1980s. Although the Sokoto agricultural and rural development authority has previously assessed the shallow groundwater in the Fadama areas of the basin "unpublished data." This study therefore to re-evaluated the groundwater resources potentials of the floodplain and Fadama alluvial aquifers by using hydraulic parameters of aquifers computed from different methods and those parameters that were not determined in early research carried out in the study area.

\section{Material and Methods}

\subsection{Physical and Climatic Settings}

Sokoto Basin is part of the larger Iullemmeden Basin of West Africa, located between latitude $10^{\circ} 00^{\prime}$ and $14^{\circ}$ $00^{\prime} \mathrm{N}$ and longitude $3^{\circ} 30^{\prime}$ and $7^{\circ} 00^{\prime} \mathrm{E}$ with total land coverage of about $65000 \mathrm{~km}^{2}$. The Basin falls within the Semi-arid climatic zone in the Sub-Saharan Sudan belt with vegetation mainly of the Savannah type. The short wet season is characterized with four months of rainfall which varies in the Basin with an annual average of 350 $\mathrm{mm}$ in at the extreme northern end to about $670 \mathrm{~mm}$ at the Sokoto airport. The longer dry season is Characterize with higher temperature and dusty conditions during the Harmatan. Temperature range of between 25.5 to $40^{\circ} \mathrm{C}$ has been recorded in the Basin [9]. Physiographically the Basin can be divided into three regions: the high plains of the east and South-east which consist of dissected plateau of crystalline rocks which are characterized by ranges of hills and massive Inselbergs which intersect steeply with the surrounding plains, the Sokoto plains of the north and central zone and the riverine region of the Niger and lower Rima valley [10]. The sedimentary basin consists of monotonous plains that are undulating with height varying between 250 and $400 \mathrm{~m}$ above sea level. The plain is occasionally interrupted by the Dange scarp which is a steep-sided topped hill with low escarpment $[11,12]$. The valleys are occupied by the Alluvial Floodplains and Rivers, Major rivers that drain the Sokoto Basin includes the Rima, Sokoto, and a Part of the Niger, Gulbin ka, Bunsuru, Zamfara, Gagare and their tributaries Figure 1. Three depositional environment have being identified; the present active channel, an intermediate and older levels. The width of the Floodplains varies from 0.5 to $15 \mathrm{~km}$ with its surface characterized with erosion and depositional features which includes abandoned Channels, ponds, pans, oxbows, braided channels, meander scars, point bars and low in- channel benches. The Fadama land in the Sokoto basin comprises the floodplains of the Niger and Sokoto-Rima and the land along the tributaries together with the shallow depressions and valley heads which dissect the upland.

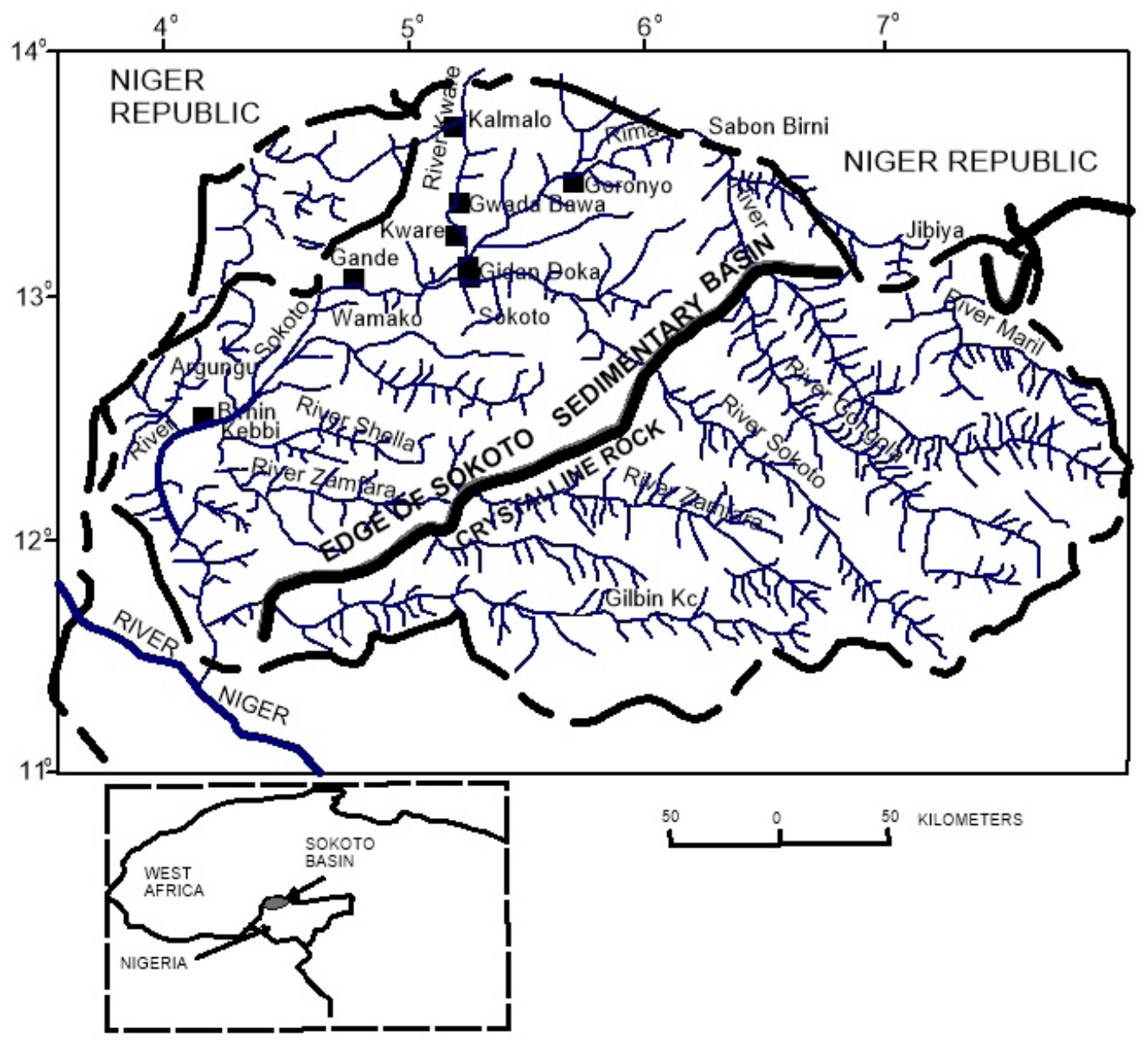

Figure 1. Drainage Map of Sokoto Basin Showing Major and Minor rivers, (modified from Adelana et al 2006) 


\subsubsection{Geology and Hydrogeology}

The Geology of the Sokoto Basin have been studied by different Scholars notably among these are the works of $[11,13,14,15]$. The summary of their findings are generalized as follows; Sokoto Basin is made up of undulating plains with an average elevation of 250-400metres above sea level. It consists of sediments which were accumulated during four main depositional phases, a Pre-Maastrichtian (Continental intercalaire) consisting of late Jurassic to early Cretaceous Gundumi and Illo Formations which rests uncoformably on the basement complex. The Gundumi Formation with an average thickness of 350metres, is made up of basal conglomerates, gravel with sands and variegated clays. The Illo Formation is made up of interbedded clay grits, pisolithic and nodular clays with a maximum thickness of about 240 meters. The second phase in the depositional history of the sediments of the Sokoto Basin began during the Maastrichtian, when the Rima Group was deposited uncoformably on pre-Maastrichtian continental beds. The Rima Group is made up of mudstones and friable sandstones (Taloka and Wurno) separated by fossiliferous Dukamaje Formation. The Paleocene Sokoto Group overlies the Rima group and consists of Dange and Gamba Formations Shales separated by calcareous Kalambaina Formation. The Post-Paleocene is represented by the Eocene-Miocene Gwandu Formation consisting of tabular hills or low hummocks over the dip slope of Sokoto Group. The Cretaceous and Tertiary formations of the Sokoto basin strike in a north-east direction and dip toward the center of the basin in a northwest direction at low angles of less than $10^{\circ}$. The succession has an average thickness of more than $1200 \mathrm{~m}$ near its border with Niger republic Figure 2.

Studies on the Hydrogeology of the Sokoto basin was first carried out by [13]. A more detail hydrogeology of the Aquifer of the Basin was provided by the work of [16]. The main water bearing aquifers in the Basin comprises of overlaying laterites, shallow floodplain alluvial sediments consisting of gravels, sands, silts and clays this constitutes high water bearing aquifers. Other water bearing formations of the basin includes Sandstones and grits of the Gwandu Formation, the Calcareous limestone perched water aquifer of the Kalambaina Formation, Sandstones of the Wurno and Taloka Formations within the Rima group and the underlying Grits and Sandstones aquifers of the Gundumi and Illo Formations. These water bearing aquifers are either confined or semi confined due to the presence of impervious Clay intercalations which resulted into artesian conditions in some areas in the Basin especially in the Gundumi and Gwandu Formations.

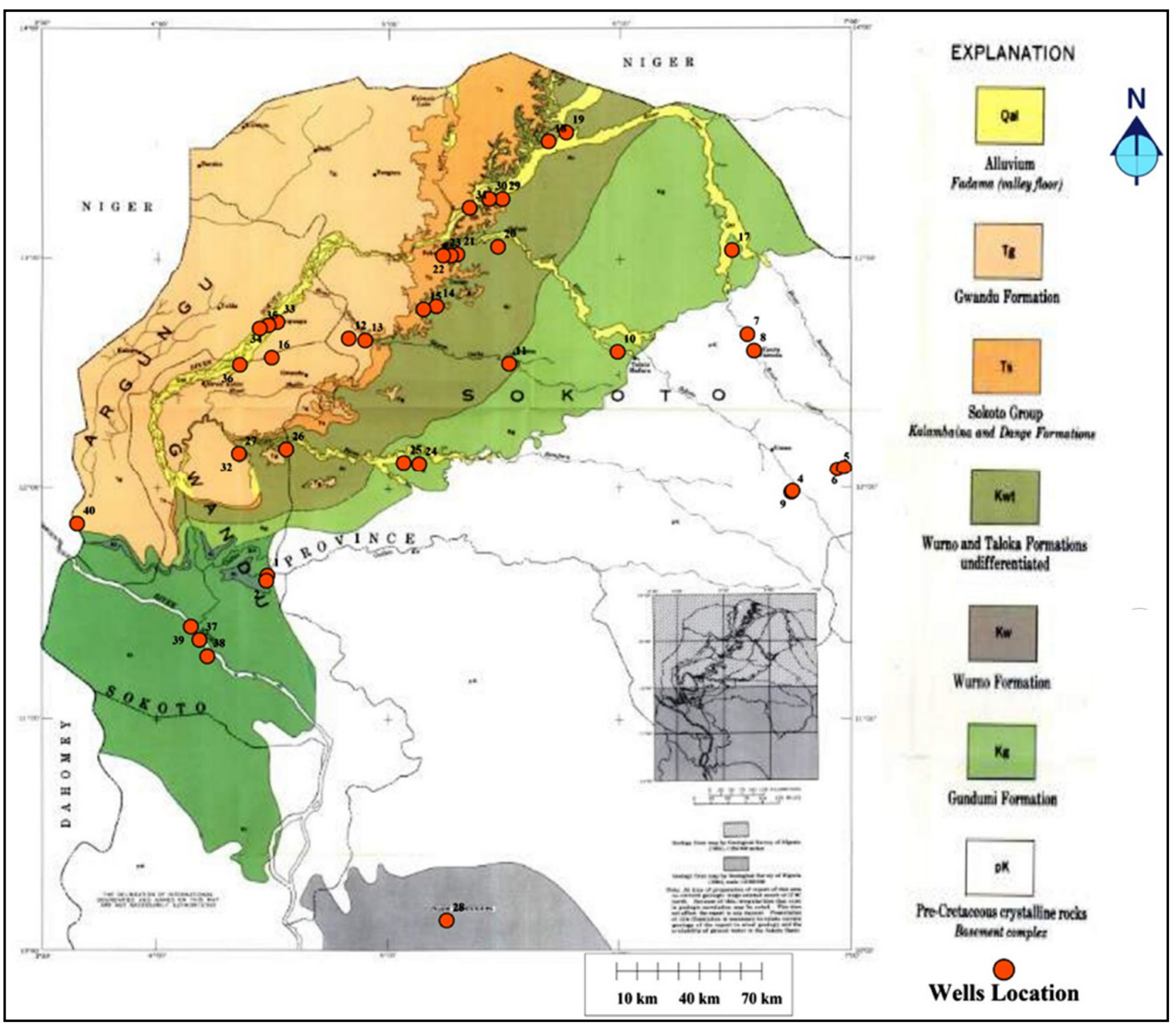

Figure 2. Geological map of Sokoto Basin with Tub wells location on the Fadama plains (adopted and modified from Anderson and Ogilbee 1973) 
$[9,17,18,19,20]$, estimated the water storage, yield and hydraulic properties for the different aquifers in the basin; a yield range of 5,850 to 25,200lph was recorded for the Gundumi/Illo formations for an artesian boreholes with a drawdown of $30 \mathrm{~m}$ and a Transmissivity range of $5.6 \mathrm{~m}^{2}$ day to $72 \mathrm{~m}^{2} /$ day. In the Taloka formation yield range for the aquifers are between 4,500 lph and 41,400 lph while drawdown ranges from 0 to $36.6 \mathrm{~m}$ depending on the location, Transmissivity obtained for the Formation are between $76 \mathrm{~m}^{2} /$ day and $118 \mathrm{~m}^{2} /$ day while Specific capacity and Storage ranges of $2.94 \mathrm{lpm} / \mathrm{m}$ dd to 4.25 $\mathrm{lpm} / \mathrm{m}$ dd and $2.57 \times 10^{-2}$ to $2.58 \times 10^{-2}$ respectively. The Wurno Formation aquifers have moderate yield range of 22,500 lph to $31500 \mathrm{lph}$, Specific capacity computed ranges between $0.45 \mathrm{lpm} / \mathrm{m}$ dd and $10.9 \mathrm{lpm} / \mathrm{m}$ dd. The Transmissivity of the Wurno aquifer is between $52 \mathrm{~m}^{2} / \mathrm{h}$ and $440 \mathrm{~m}^{2} / \mathrm{h}$, with a storage estimated to be $4.0 \times 10^{-3}$. Kalambaina limestone aquifer has a recorded yield of between $6300 \mathrm{lph}$ and 54,400 lph with a maximum drawdown of $12.8 \mathrm{~m}$, Transmissivity value obtained was as high as $2,210 \times \mathrm{m}^{2} /$ day while Storativity value of 2.43 $10^{-3}$ was calculated for the limestone aquifer. Gwandu formation is the most prolific in terms of Groundwater potential in the Sokoto basin, artesian aquifer occurred within this formation. The most prolific aquifer in the Gwandu is the lower zone aquifer with free flow of well as high as $54000 \mathrm{lph}$ obtained with a maximum head recorded value of $25.3 \mathrm{~m}$. Transmissivity value as high as
$2,530 \mathrm{~m}^{3} /$ day was obtained for the aquifers in the in Gwandu.

\subsubsection{Sources of Data and Evaluation Methods}

Acquisition of recent, reliable and accurate pumping test data was the biggest challenge of this study. Therefore the data for this study was obtained from the Sokoto Agricultural and Rural Development Authority (SARDA) report" Unpublished data" . A total of forty Tube wells pumping test, lithological logs and tube wells information were used to compute the required hydraulic parameters for the assessment of the groundwater potentials of the shallow alluvial aquifers beneath the Fadama and floodplains of the Sokoto basin. Hydraulic conductivity was determined from Transmissivity and aquifer thickness, while Drawdown and Discharge data were used to evaluate Specific capacity. The Storativity was determined using [21] method from known lithology by multiplying the standard specific storage value of the known aquifer lithology with aquifer thickness. The aquifer thickness was estimated from drill logs of the tube wells. The drill cuttings data were used to construct the lithological logs of the Tube wells using Sedlog software. The various hydraulic parameters computed were subjected to statistical analysis to see how they are related to each other; an IBM SPSS statistical software package version 22 for windows was used for the statistical treatment of the hydraulic parameters, Table 1.

Table 1. Pumping Test and Tube well Data of the Studied Wells

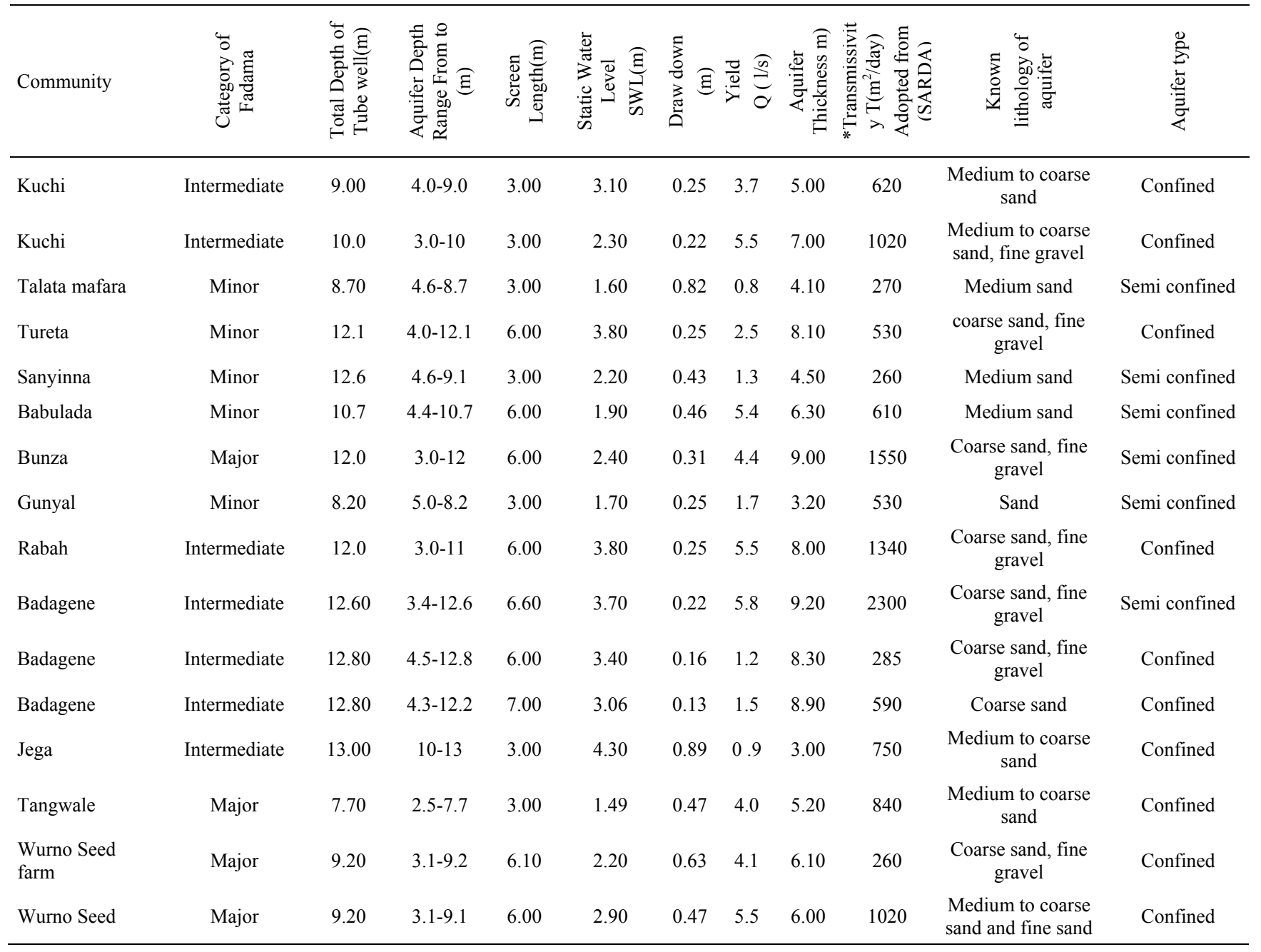




\begin{tabular}{|c|c|c|c|c|c|c|c|c|c|c|c|}
\hline Community & 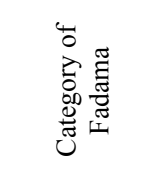 & 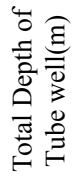 & 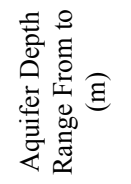 & 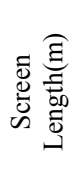 & 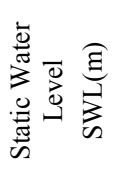 & 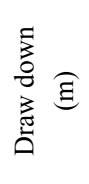 & $\stackrel{\frac{\pi}{2}}{\stackrel{2}{\Xi}}$ & 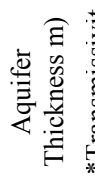 & 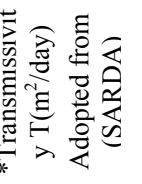 & 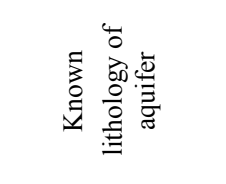 & 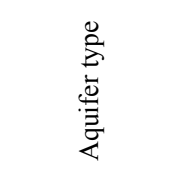 \\
\hline Lukwa & Major & 10.0 & $4.0-10$ & 6.00 & 2.90 & 0.31 & 1.2 & 6.00 & 300 & $\begin{array}{l}\text { Medium to coarse } \\
\text { sand }\end{array}$ & Confined \\
\hline Bunza & Major & 11.0 & $2.0-11$ & 3.00 & 2.40 & 0.31 & 5.0 & 9.00 & 3950 & $\begin{array}{l}\text { Coarse sand, fine } \\
\text { gravel }\end{array}$ & Semi confined \\
\hline Argungu & Major & 9.00 & $4.0-9$ & 3.00 & 4.10 & 0.82 & 5.6 & 5.00 & 290 & Fine gravel & Semi confined \\
\hline Argungu & Major & 9.00 & $4.3-9.0$ & 3.00 & 3.20 & 0.47 & 5.6 & 4.70 & 800 & $\begin{array}{l}\text { Medium to coarse } \\
\text { sand }\end{array}$ & Semi confined \\
\hline Dabire & Major & 8.90 & $3.0-8.9$ & 4.00 & 1.90 & 1.28 & 3.7 & 5.90 & 180 & $\begin{array}{l}\text { Medium to coarse } \\
\text { sand }\end{array}$ & Semi confined \\
\hline Bagudo & Major & 16.0 & $4.0-16$ & 3.70 & 1.30 & 0.61 & 2.2 & 12.0 & 1740 & $\begin{array}{l}\text { Medium sand, } \\
\text { gravel }\end{array}$ & Confined \\
\hline Tugan Ulu & Major & 7.30 & $1.5-7.3$ & 3.00 & 1.40 & 0.31 & 2.8 & 3.00 & 440 & coarse sand & Confined \\
\hline Tungan Bako & Major & 17.0 & $1.2-17$ & 6.00 & 3.10 & 0.12 & 5.5 & 11.00 & 910 & $\begin{array}{c}\text { Coarse sand, fine } \\
\text { gravel }\end{array}$ & Confined \\
\hline Yanwari/Gurbi & Minor & 5.60 & $1.5-5.6$ & 3.00 & 2.80 & 0.44 & 6.4 & 4.10 & 320 & $\begin{array}{l}\text { Coarse sand, fine } \\
\text { gravel }\end{array}$ & Semi confined \\
\hline Mada & Minor & 8.50 & $4.7-8.5$ & 6.00 & 2.10 & 0.45 & 1.6 & 3.80 & 210 & $\begin{array}{l}\text { Coarse sand, fine } \\
\text { gravel }\end{array}$ & Confined \\
\hline Mada & Minor & 7.30 & $4.7-7.3$ & 3.00 & 2.10 & 0.63 & 2.7 & 2.60 & 175 & $\begin{array}{l}\text { Coarse sand, fine } \\
\text { gravel }\end{array}$ & Confined \\
\hline Jabaka & Minor & 7.80 & $1.3-7.8$ & 3.00 & 1.40 & 0.63 & 2.2 & 6.50 & 200 & Medium sand & Confined \\
\hline Daba & Minor & 8.00 & $3.3-6.7$ & 4.00 & 3.30 & 0.25 & 4.0 & 4.70 & 1060 & $\begin{array}{l}\text { Coarse sand, fine } \\
\text { gravel }\end{array}$ & Semi confined \\
\hline $\begin{array}{l}\text { Gidan Sambo } \\
\text { K/namoda }\end{array}$ & Minor & 7.80 & $3.5-7.8$ & 3.00 & 3.60 & 0.18 & 4.0 & 4.80 & 1580 & Sand & Confined \\
\hline Gidan Fakai & Minor & 7.80 & $3.3-7.8$ & 3.00 & 3.10 & 0.25 & 1.6 & 4.50 & 270 & Coarse sand & Confined \\
\hline Danchadi & Minor & 10.60 & $5.0-10.6$ & 6.00 & 3.60 & 2.45 & 0.3 & 5.60 & 40 & $\begin{array}{l}\text { Fine to Medium } \\
\text { sand }\end{array}$ & Semi confined \\
\hline $\begin{array}{l}\text { Bodinga/Dancha } \\
\text { di }\end{array}$ & Minor & 19.20 & $12.8-19.2$ & 6.40 & 4.09 & 0.29 & 2.7 & 6.40 & 620 & Medium sand & Semi confined \\
\hline Shinkafi & Intermediate & 14.80 & $11.2-14.8$ & 3.00 & 2.70 & 0.11 & 7.0 & 3.60 & 2320 & $\begin{array}{c}\text { Coarse sand, fine } \\
\text { gravel }\end{array}$ & Confined \\
\hline Kaddi & Intermediate & 9.70 & $6.7-9.7$ & 3.00 & 3.90 & 0.26 & 3.2 & 3.00 & 360 & Coarse sand & Semi confined \\
\hline Tsui uru & Intermediate & 8.50 & $1.5-8.5$ & 7.00 & 1.40 & 0.36 & 2.4 & 7.00 & 630 & $\begin{array}{l}\text { Coarse sand, fine } \\
\text { gravel }\end{array}$ & Confined \\
\hline Gummi & Intermediate & 12.80 & $6.7-12.8$ & 6.10 & 3.40 & 0.89 & 2.2 & 6.10 & 160 & $\begin{array}{l}\text { Medium sand to } \\
\text { fine sand }\end{array}$ & Semi confined \\
\hline Gummi & Intermediate & 23.50 & $3.8-12$ & 6.00 & 3.30 & 0.47 & 2.5 & 8.20 & 790 & $\begin{array}{l}\text { Coarse sand, fine } \\
\text { gravel }\end{array}$ & Semi confined \\
\hline Romo & Intermediate & 12.00 & $8.5-10.7$ & 2.20 & 2.70 & 0.29 & 2.8 & 3.50 & 770 & $\begin{array}{l}\text { Coarse sand, fine } \\
\text { gravel }\end{array}$ & Confined \\
\hline Kamba & Major & 10.00 & $5.0-10$ & 5.00 & 1.10 & 0.38 & 5.5 & 5.00 & 1090 & $\begin{array}{l}\text { Coarse sand, fine } \\
\text { gravel }\end{array}$ & Semi confined \\
\hline
\end{tabular}

* Note that Transmissivity values were adopted from Sokoto Agricultural and Rural Development Authority(SARDA) "Unpublised data".

The following equations were used to compute the hydraulic properties of the aquifers:

The Storativity of the confined to semi - confined aquifers were evaluated using the equation

$$
\mathbf{S}=\mathbf{S s} \times \mathrm{b}
$$

$\mathrm{S}=$ Storativity which is dimensionless

Ss $=$ Specific Storage

$\mathrm{b}=$ Aquifer thickness

Hydraulic conductivity was calculated using

$$
\mathrm{K}=\mathrm{T} / \mathrm{B}
$$

Where $\mathrm{K}=$ Hydraulic conductivity (m/day)
$\mathrm{B}=$ Screen length used.

Specific capacity was calculated using

$$
\mathrm{Q} / \mathrm{s}
$$

Where

$\mathrm{S}=$ total drawdown recorded in pumping well

$\mathrm{Q}=$ Discharge or Yield of borehole in $(1 / \mathrm{s})$

Specific capacity is in $\mathrm{m}^{3} /$ day

\section{Results and Discussions}

The results are presented in Table 2 below. 
Table 2. Computed Hydraulic Parameters of the Studied Tube wells in the Area

\begin{tabular}{|c|c|c|c|c|c|}
\hline Community & $\begin{array}{c}\text { Standard } \\
\text { Specific } \\
\text { storage }\left(\mathbf{m}^{-1}\right) \\
\end{array}$ & $\begin{array}{l}\text { Calculated Storativity (S) } \\
\text { using Younger (1993) } \\
\text { method(Present study) }\end{array}$ & $\begin{array}{c}\text { *Adopted Storativity } S \text { using } \\
\text { Cooper Jacob (1946) } \\
\text { method(SARDA) }\end{array}$ & $\begin{array}{c}\text { Hydraulic } \\
\text { Conductivity K } \\
\text { (m/day) } \\
\end{array}$ & $\begin{array}{c}\text { Specific } \\
\text { capacity } \\
\left(\mathrm{m}^{3} / \mathrm{day} /\right)\end{array}$ \\
\hline Kuchi & $9.87 \times 10^{-5}$ & $5 \times 10^{-4}$ & $3 \times 10^{-3}$ & 206.60 & 1231 \\
\hline Kuchi & $9.87 \times 10^{-5}$ & $7 \times 10^{-4}$ & $4 \times 10^{-3}$ & 340.00 & 1320 \\
\hline Talata mafara & $9.87 \times 10^{-5}$ & $4 \times 10^{-4}$ & $4 \times 10^{-2}$ & 90.00 & 86.60 \\
\hline Tureta & $1.05 \times 10^{-5}$ & $8 \times 10^{-5}$ & $5 \times 10^{-3}$ & 88.30 & 864.00 \\
\hline Sanyinna & $9.87 \times 10^{-5}$ & $4 \times 10^{-4}$ & $1 \times 10^{-3}$ & 86.60 & 267 \\
\hline Babulada & $9.87 \times 10^{-5}$ & $6 \times 10^{-4}$ & $3 \times 10^{-1}$ & 101.60 & 1015 \\
\hline Bunza & $1.05 \times 10^{-5}$ & $9 \times 10^{-5}$ & $4 \times 10^{-5}$ & 258.30 & 1226 \\
\hline Gunyal & $9.87 \times 10^{-5}$ & $3 \times 10^{-4}$ & $4 \times 10^{-5}$ & 176.60 & 576 \\
\hline Rabah & $1.05 \times 10^{-5}$ & $8 \times 10^{-5}$ & $2 \times 10^{-2}$ & 223.00 & 1912 \\
\hline Badagene & $1.05 \times 10^{-5}$ & $9 \times 10^{-5}$ & $5 \times 10^{-5}$ & 348.50 & 2290 \\
\hline Badagene & $1.05 \times 10^{-5}$ & $9 \times 10^{-5}$ & $1 \times 10^{-1}$ & 66.30 & 1000 \\
\hline Jega & $1.05 \times 10^{-5}$ & $3 \times 10^{-5}$ & $2 \times 10^{-1}$ & 250.0 & 96.60 \\
\hline Tangwale & $1.05 \times 10^{-5}$ & $5 \times 10^{-5}$ & $2 \times 10^{-4}$ & 280.0 & 736.2 \\
\hline Wurno Seed farm & $1.05 \times 10^{-5}$ & $6 \times 10^{-5}$ & $2 \times 10^{-2}$ & 42.60 & 563.5 \\
\hline Wurno Seed & $9.82 \times 10^{-4}$ & $6 \times 10^{-3}$ & $9 \times 10^{-4}$ & 170.0 & 1004 \\
\hline Lukwa & $9.87 \times 10^{-5}$ & $6 \times 10^{-4}$ & $3 \times 10^{-3}$ & 50.00 & 322.60 \\
\hline Bunza & $1.05 \times 10^{-5}$ & $9 \times 10^{-5}$ & $2 \times 10^{-5}$ & 1316 & 1878 \\
\hline Argungu & $1.05 \times 10^{-5}$ & $5 \times 10^{-5}$ & $2 \times 10^{-3}$ & 96.60 & 590 \\
\hline Argungu & $1.05 \times 10^{-5}$ & $5 \times 10^{-5}$ & $2 \times 10^{-2}$ & 266.60 & 1152 \\
\hline Dabire & $1.05 \times 10^{-5}$ & $6 \times 10^{-5}$ & $3 \times 10^{-3}$ & 45.00 & 247.60 \\
\hline Bagudo & $1.05 \times 10^{-5}$ & $1 \times 10^{-4}$ & $3 \times 10^{-2}$ & 470 & 311 \\
\hline Tungan Bako & $1.05 \times 10^{-5}$ & $1 \times 10^{-4}$ & $1 \times 10^{-2}$ & 151.60 & 3958 \\
\hline Yanwari/Gurbi & $1.05 \times 10^{-5}$ & $4 \times 10^{-5}$ & $7 \times 10^{-3}$ & 106.60 & 1256.8 \\
\hline Mada & $1.05 \times 10^{-5}$ & $4 \times 10^{-5}$ & $6 \times 10^{-4}$ & 35 & 306.60 \\
\hline Mada & $1.05 \times 10^{-5}$ & $3 \times 10^{-5}$ & $1 \times 10^{-2}$ & 58 & 365 \\
\hline Jabaka & $9.87 \times 10^{-5}$ & $6 \times 10^{-4}$ & $6 \times 10^{-4}$ & 66.70 & 301.50 \\
\hline Daba & $1.05 \times 10^{-5}$ & $5 \times 10^{-5}$ & $5 \times 10^{-2}$ & 265 & 1384 \\
\hline Gidan Sambo K/namoda & $1.05 \times 10^{-5}$ & $5 \times 10^{-5}$ & $1 \times 10^{-1}$ & 526.60 & 1922 \\
\hline Gidan Fakai & $1.05 \times 10^{-5}$ & $5 \times 10^{-5}$ & $5 \times 10^{-2}$ & 90 & 552 \\
\hline Danchadi & $9.87 \times 10^{-5}$ & $5 \times 10^{-4}$ & $2 \times 10^{-3}$ & 6.66 & 12.25 \\
\hline Bodinga/Danchadi & $9.87 \times 10^{-5}$ & $6 \times 10^{-4}$ & $2 \times 10^{-3}$ & 96.80 & 820 \\
\hline Shinkafi & $1.05 \times 10^{-5}$ & $1 \times 10^{-5}$ & $9 \times 10^{-2}$ & 773 & 5763.6 \\
\hline Kaddi & $1.05 \times 10^{-5}$ & $3 \times 10^{-5}$ & $3 \times 10^{-3}$ & 120 & 1061 \\
\hline Tsui uru & $1.05 \times 10^{-5}$ & $7 \times 10^{-5}$ & $3 \times 10^{-3}$ & 90 & 577 \\
\hline Gummi & $9.82 \times 10^{-4}$ & $6 \times 10^{-3}$ & $5 \times 10^{-4}$ & 26.20 & 212 \\
\hline Gummi & $1.05 \times 10^{-5}$ & $8 \times 10^{-5}$ & $8 \times 10^{-7}$ & 327 & 831 \\
\hline Romo & $1.05 \times 10^{-5}$ & $1 \times 10^{-5}$ & $1 \times 10^{-5}$ & 767.8 & 831 \\
\hline Kamba & $1.05 \times 10^{-5}$ & $5 \times 10^{-5}$ & $4 \times 10^{-4}$ & 363 & 1250 \\
\hline
\end{tabular}

\subsection{Tube Wells properties}

\subsubsection{Yield}

Tube wells Yield varies between $0.3 \mathrm{l} / \mathrm{s}$ and $7.0 \mathrm{l} / \mathrm{s}$, with thirty (30) tube wells having yields above $2.0 \mathrm{l} / \mathrm{s}$. Ten (10) tube wells have yields that are below $2.0 \mathrm{l} / \mathrm{s}$, six (6) wells out of this are located within the minor Fadama, while three (3) on the intermediate with only one (1) is located on the major Fadama. Recorded yield values of the studied tube wells indicated the tube well at Shinkafi which was drilled on the intermediate Fadama of river Bunsuru floodplain as having the highest yield of $7 \mathrm{l} / \mathrm{s}$, this tube well with a depth of $14.8 \mathrm{~m}$ consist of Aquiferous zones which composed of coarse sand and gravels materials confined between a top clay layer and a bottom hard formation of ironstone. The tube well at Danchadi with the lowest yield of $0.3 \mathrm{l} / \mathrm{s}$ was located on the Gaminda minor Fadama with a total depth of $10.6 \mathrm{~m}$, lithological borehole 
$\log$ for this tube well revealed a silt, clayey silty fine sand, fine to medium sand sequence with iron stone at the bottom, with aquifer materials that consist of fine to medium sand material which were unconfined. The lithological $\operatorname{logs}$ of drilled wells used for this study correlate positively and agrees with the model produced by [22], Figures, 4a, 4b 4c and 3 respectively. However 12 wells have yields values that varies between 5.4 and $7.0 \mathrm{l} / \mathrm{s}$ these values were within the range of $5-50 \mathrm{l} / \mathrm{s}$ for unconsolidated sediments as given by [22]. Tube wells with yield values that are above $2.2 \mathrm{l} / \mathrm{s}$ have the minimum yield required for successful irrigation, [23]. [22] Pointed out that a yield of $0.5 \mathrm{l} / \mathrm{s}$ is suitable for small scale agriculture. SARDA" Unpublished data" grouped the tube wells in the Sokoto basin into three classes based on their yield, Wells with yield above $2.5 \mathrm{l} / \mathrm{s}$ are classified as high, those with yield that ranges between 1.3 and $2.5 \mathrm{l} / \mathrm{s}$ as moderate yielding wells while tube wells that cannot yield water that exceed $1.2 \mathrm{l} / \mathrm{s}$ are considered as low yielding. The yield range obtained in this study is comparable with values obtained by [24] for the major floodplains on the Gongola and Jama'are Rivers in Bauchi state which ranges from 0.6 to $9.4 \mathrm{l} / \mathrm{s}$.

\subsubsection{Static water level and Drawdown}

Measured static water levels in the non - pumping tube wells ranges between $1.10 \mathrm{~m}$ and $4.30 \mathrm{~m}$ with a mean value of $2.70 \mathrm{~m}$. Drawdown values recorded after pumping test of tube wells were between 0.11 and $2.45 \mathrm{~m}$ with an average of $0.41 \mathrm{~m}$. The least drawdown value was recorded in the tube well with highest recorded yield for this study at Shinkafi. Both the static water level and drawdown parameters depends on recharge and permeability of the aquifer, the more the permeable aquifer will experience more recharge into the aquifer, consequently a lesser drawdown in the well. The average drawdown value of $0.41 \mathrm{~m}$ has indicated that the aquifers in the area are generally efficient in terms of both recharge and discharge, pointing to good permeability.

\subsection{Hydraulic Properties of Aquifer}

\subsubsection{Storativity}

The Storativity values computed using [21] method of known aquifer lithology, a range of $1 \times 10^{-5}$ to $6 \times 10^{-3}$ with an average of $5 \times 10^{-4}$ were obtained indicating the aquifers to be predominantly confined. Comparing the values obtained for the area using the non equilibrium straight line graphical method of [25], a range of $8 \times 10^{-7}$ to $3 \times 10^{-1}$ with an average of $3 \times 10^{-2}$, it was observed that values obtained using the graphical method are higher than values obtained using [21]. However the two values comparably agreed with each other in some cases, the overall assessment revealed that the difference in values of storativity obtained from these two different methods are not much and are within the expected values for alluvial material for confined aquifers, this proved the [21] Method to be valid and correct.

\subsubsection{Transmissivity}

The values and range obtained for transmissivity ranges from 40 to $3950 \mathrm{~m}^{2}$ /day with a mean value of 799.5 $\mathrm{m}^{2} /$ day base on the standard values given by [26] and [27] while based on the average value computed for the area, the study area can generally be categorized as having high potentials for groundwater transmission and very high groundwater withdrawal of regional importance.

\subsubsection{Hydraulic Conductivity}

Hydraulic conductivity which is the ability of the aquifer material to uninterruptedly allow the free flow of water through it into the well was computed, this ranges between $6.66-1316 \mathrm{~m} /$ day with a mean of 215,044 $\mathrm{m} /$ day. Coarse sands and gravel material have higher hydraulic conductivity values. [28] showed that Unconsolidated alluvial aquifers with well sorted more matured sediment with free porous flow path tend to have higher hydraulic conductivity values compared to poorly sorted and immature sediments with low porosity, According to [29] Hydraulic conductivity is control by the intrinsic permeability of the aquifer, which includes grain size distribution, packing, sorting and interconnectivity for unconsolidated sediments and rocks. Based on the ranges of hydraulic conductivities given by [29], the computed values of four tube wells in this study falls within the range of $500-10,000 \mathrm{~m} /$ day which is the class for alluvial gravel aquifer, the remaining 36 wells are within the 1-500 $\mathrm{m} /$ day range for alluvial sands. The average value of $215,044 \mathrm{~m} /$ day has placed the floodplain aquifers of the Sokoto basin in the alluvial sands class.

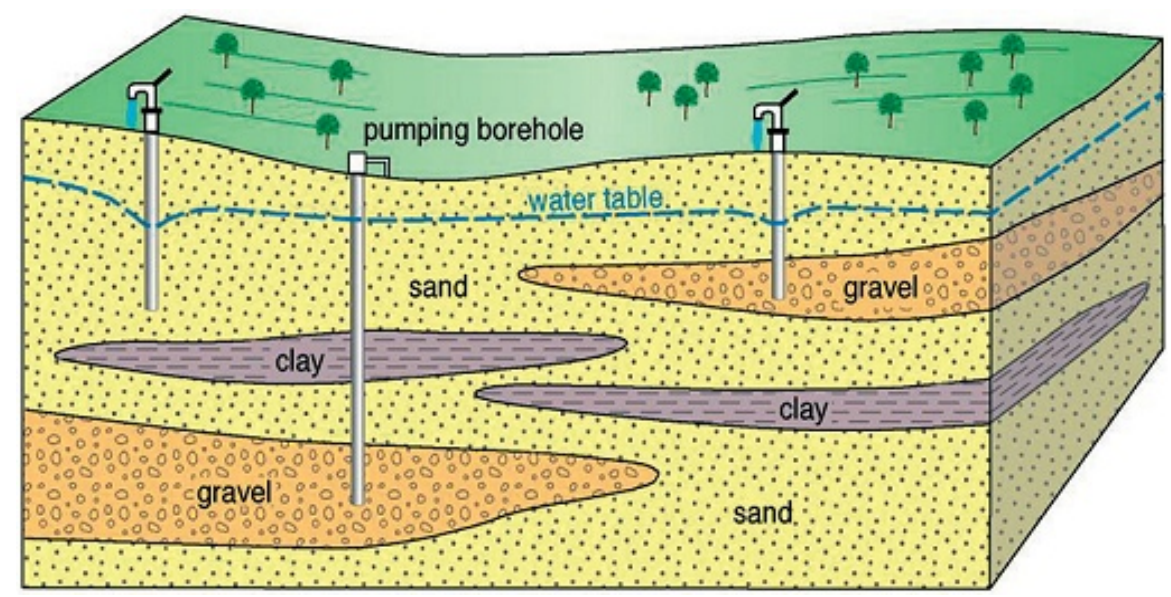

Figure 3. Unconsolidated high productive aquifer materials in Africa showing sandy and gravel water saturated units, Adopted from MacDonald et al (2011) 


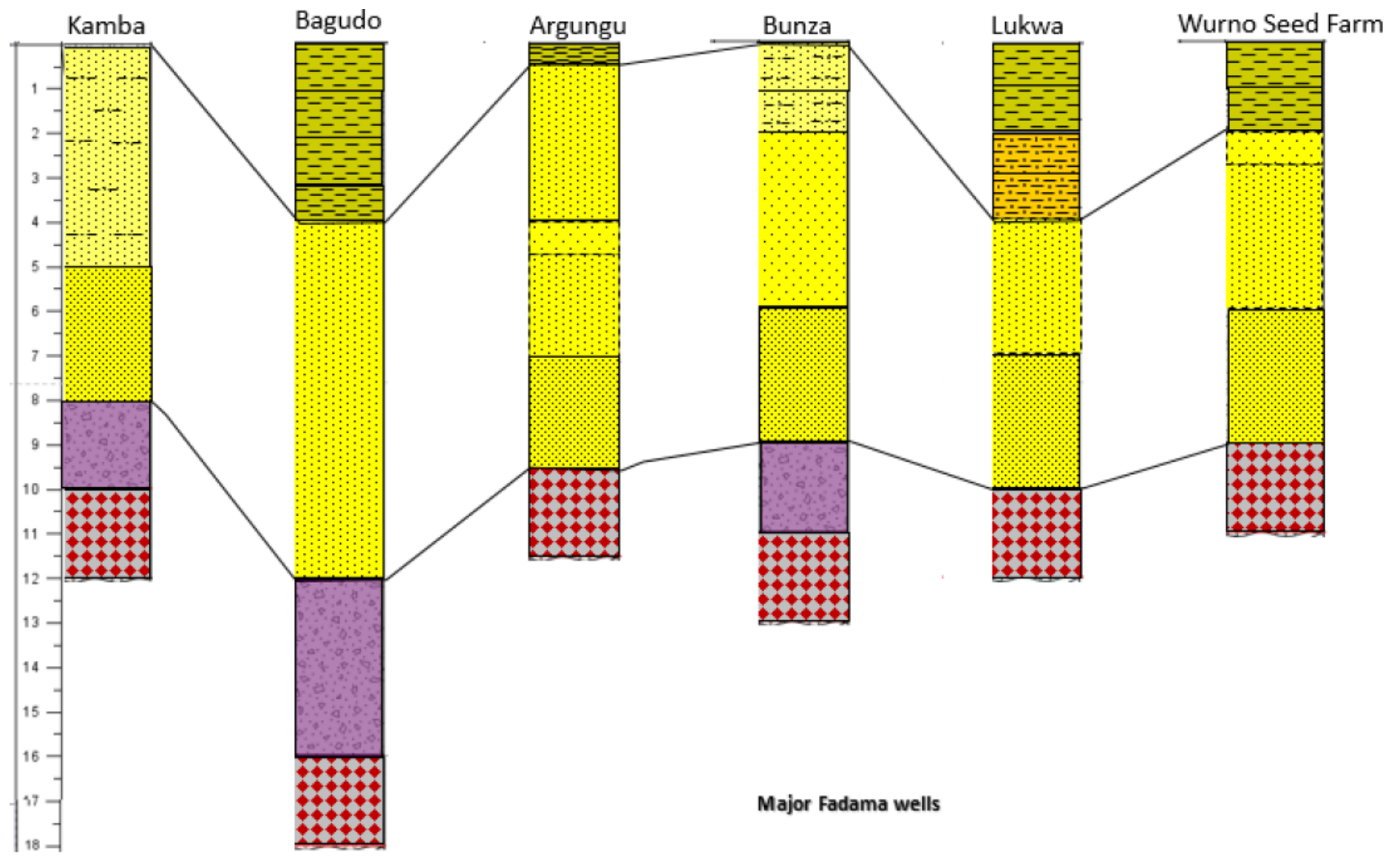

Figure 4a. Lithological logs of selected tube wells on the major Fadama in the study area

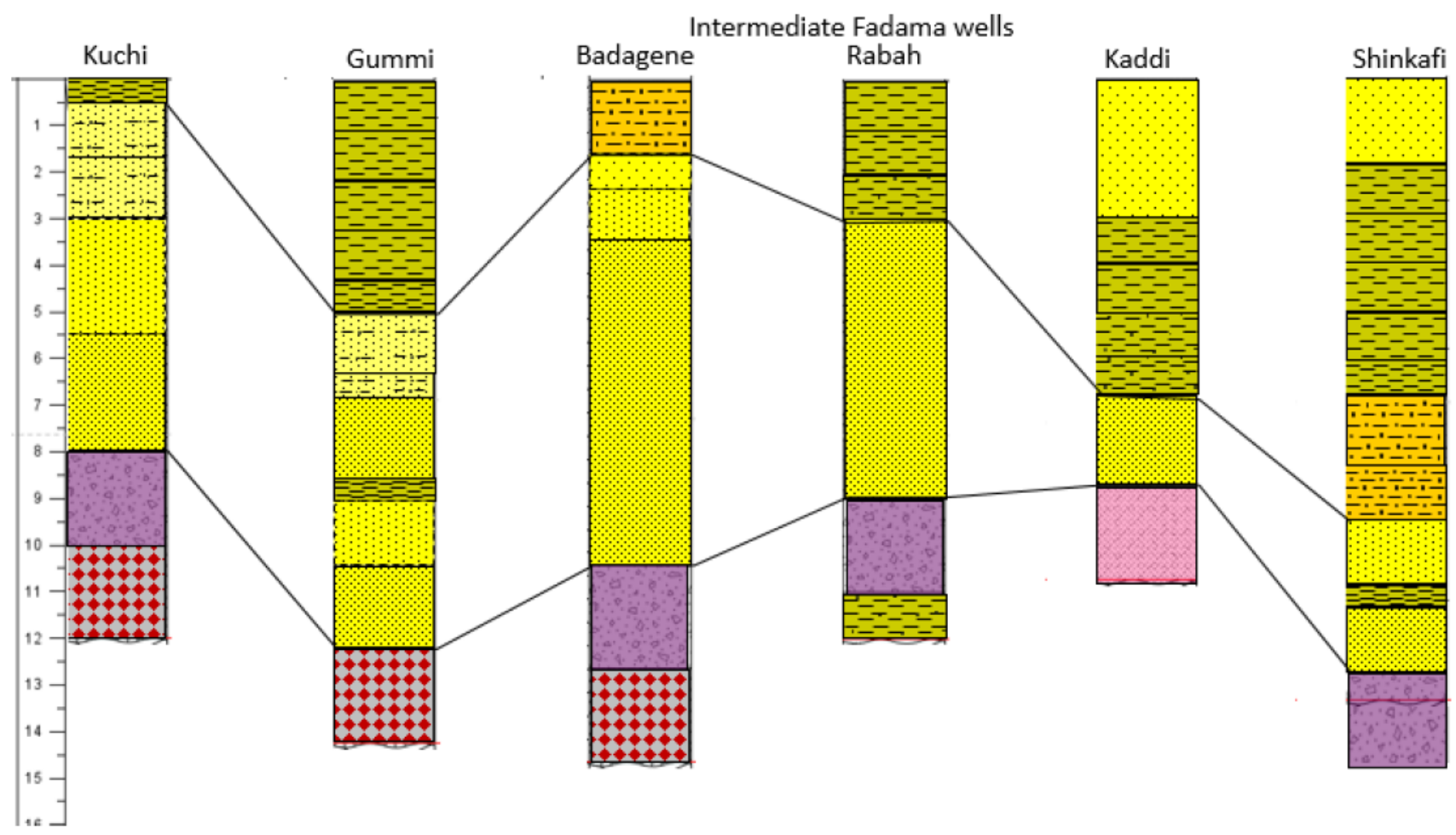

Figure 4b. Lithological logs of selected tube wells on the intermediate Fadama in the Basin of study 

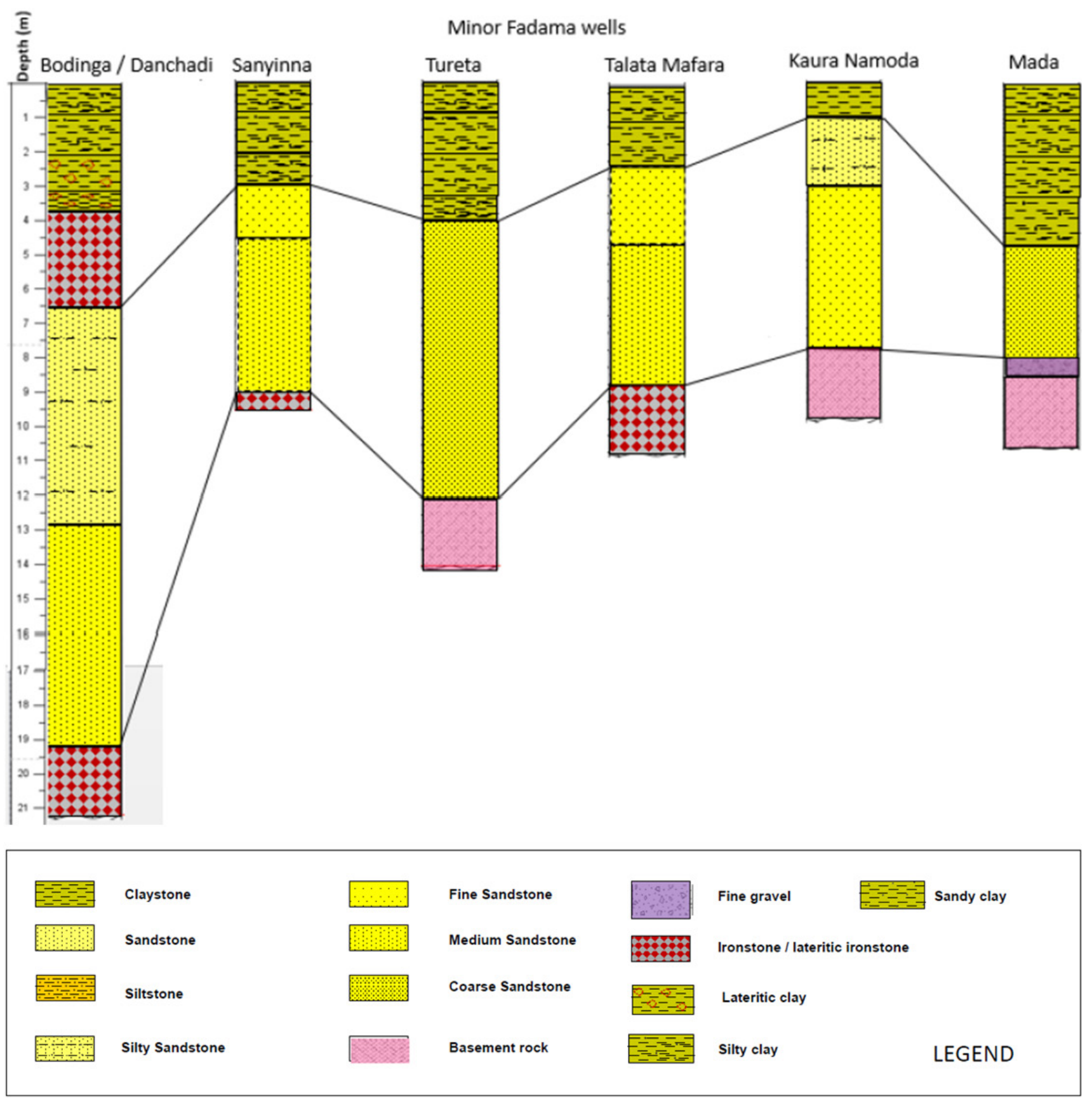

Figure 4c. Lithological logs of selected tube wells located minor on the Fadama lands of Sokoto Basin

\subsection{Shallow Groundwater Recharge}

The alluvial aquifers are recharge by precipitation, infiltration from surface waters through Stream flow and upward recharge from underlying bed rock formation in the sedimentary areas. The climate change being experienced in the region can have adverse effects on the recharge because of the reductions in the number of raining days which fluctuate during the short wet season, drying up of some of the surface water bodies during the peak of the dry season and also the activities of gravel miners along the rivers and floodplains have negative impact on the recharging of the shallow alluvial aquifers. This can drastically reduce the quantity of water that can be taken into storage through the different recharge processes. However base on water level monitoring in some tube wells the seasonal variation in water levels in the shallow alluvial aquifers in the area is between 0.2 to $2.4 \mathrm{~m}$.

\subsection{Statistical Evaluation of Computed Hydraulic Characteristic}

Statistical analysis to know the relationship between some of the calculated aquifer properties revealed that Specific capacity is linearly related to the Yield, Transmissivity, and hydraulic conductivity similarly Comparison between Transmissivity gives a linear relationship with Hydraulic conductivity and the Yields of tube wells, Figures $5 \mathrm{a}$ to $5 \mathrm{e}$. This is an indication of the interdependency of these parameters on each other and how they can affect the performance, productivity and efficiency of the shallow alluvial aquifer ability to function properly as water storing and transmitting medium. 


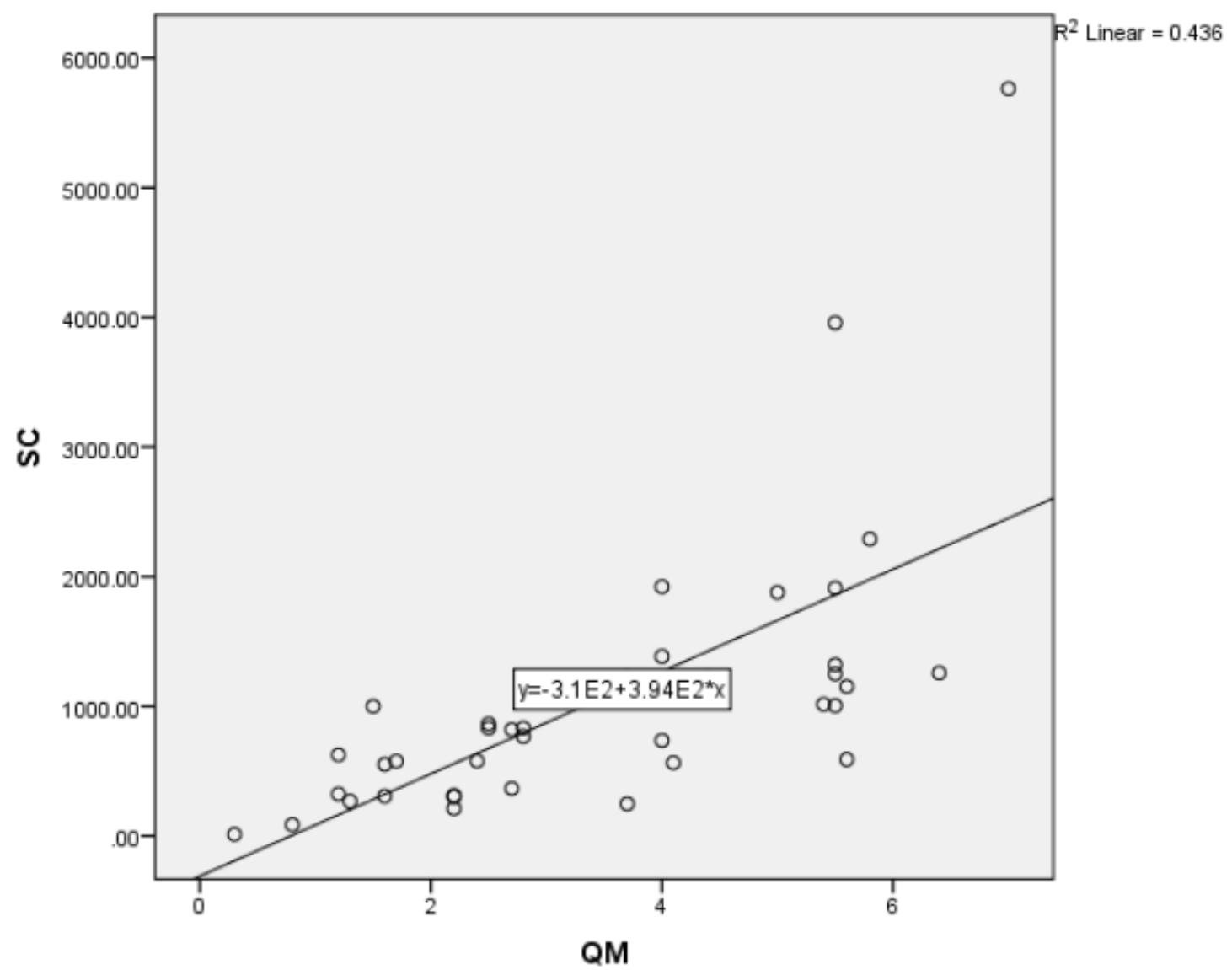

Figure 5a. A plot of specific capacity verses yield

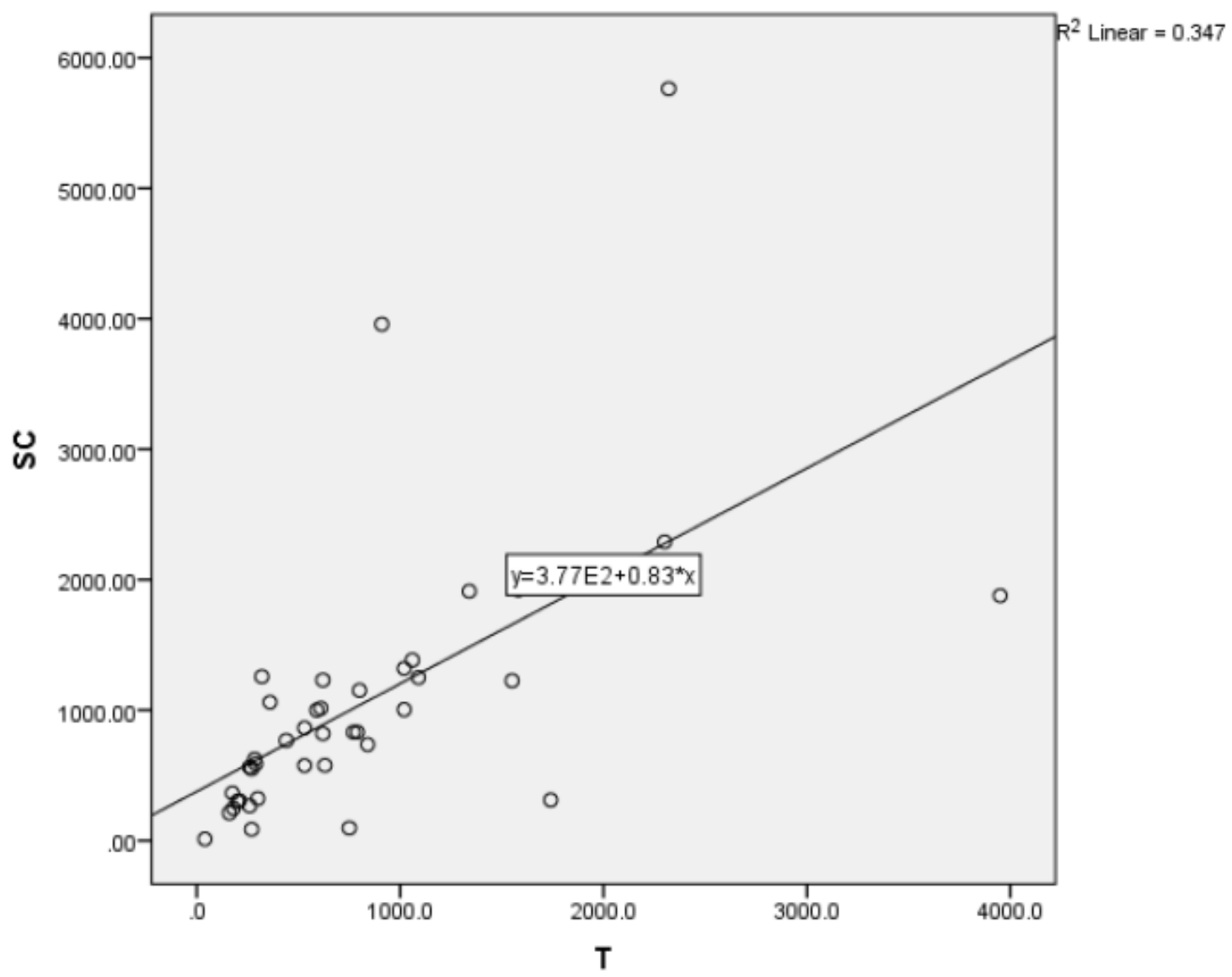

Figure 5b. A plot of specific capacity against Transmissivity 


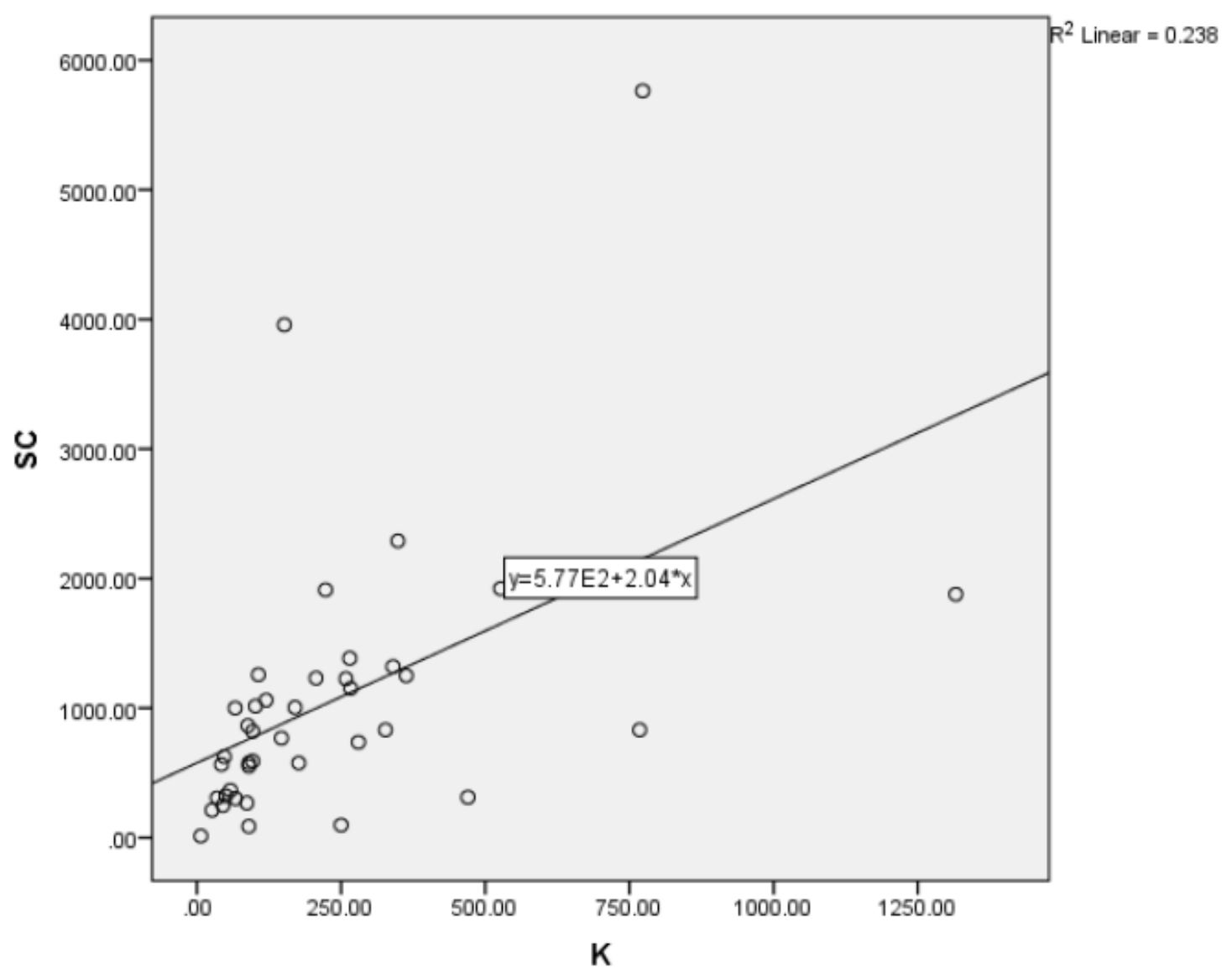

Figure 5c. A plot of specific capacity against hydraulic conductivity

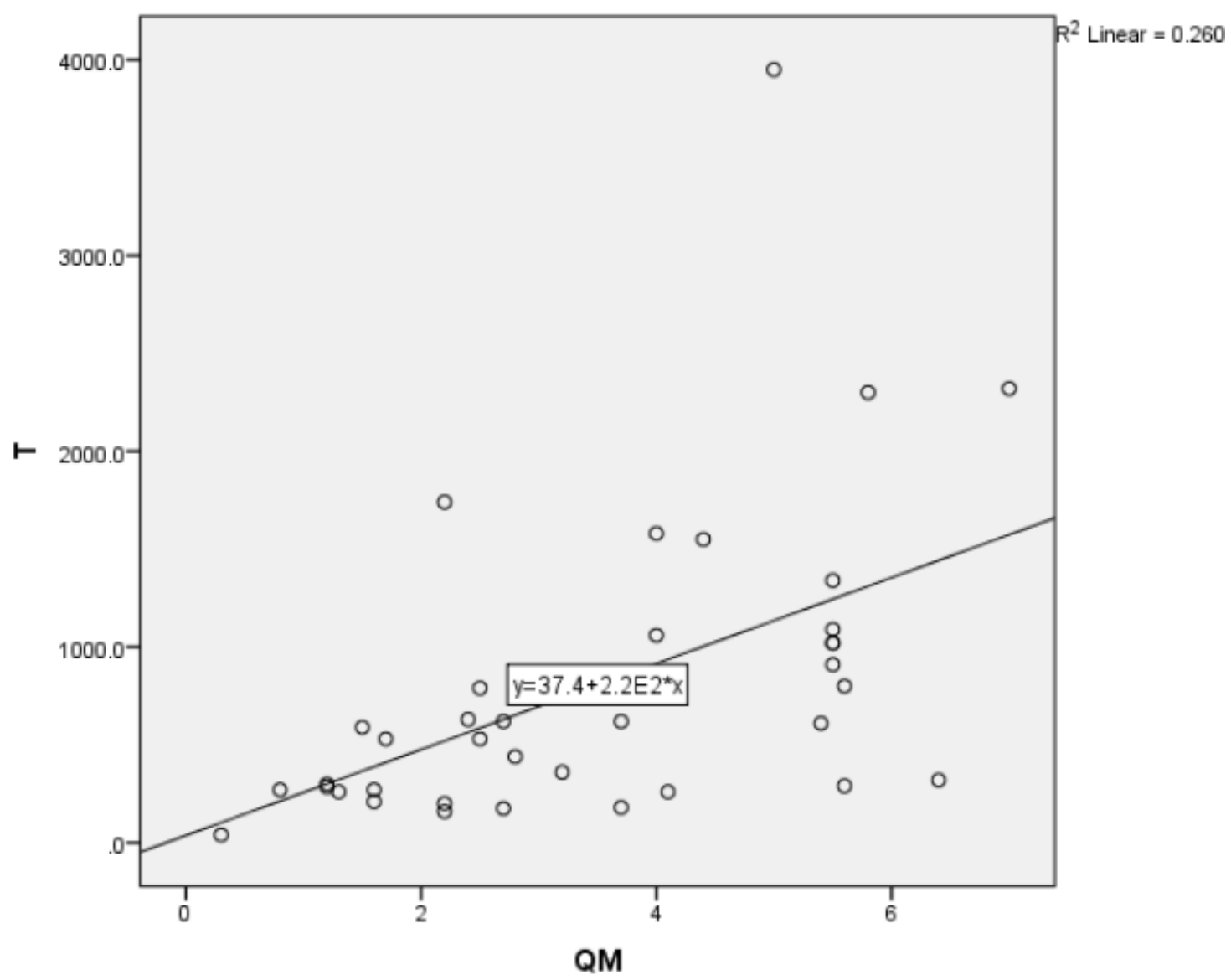

Figure 5d. A plot of Transmissivity verses yield 


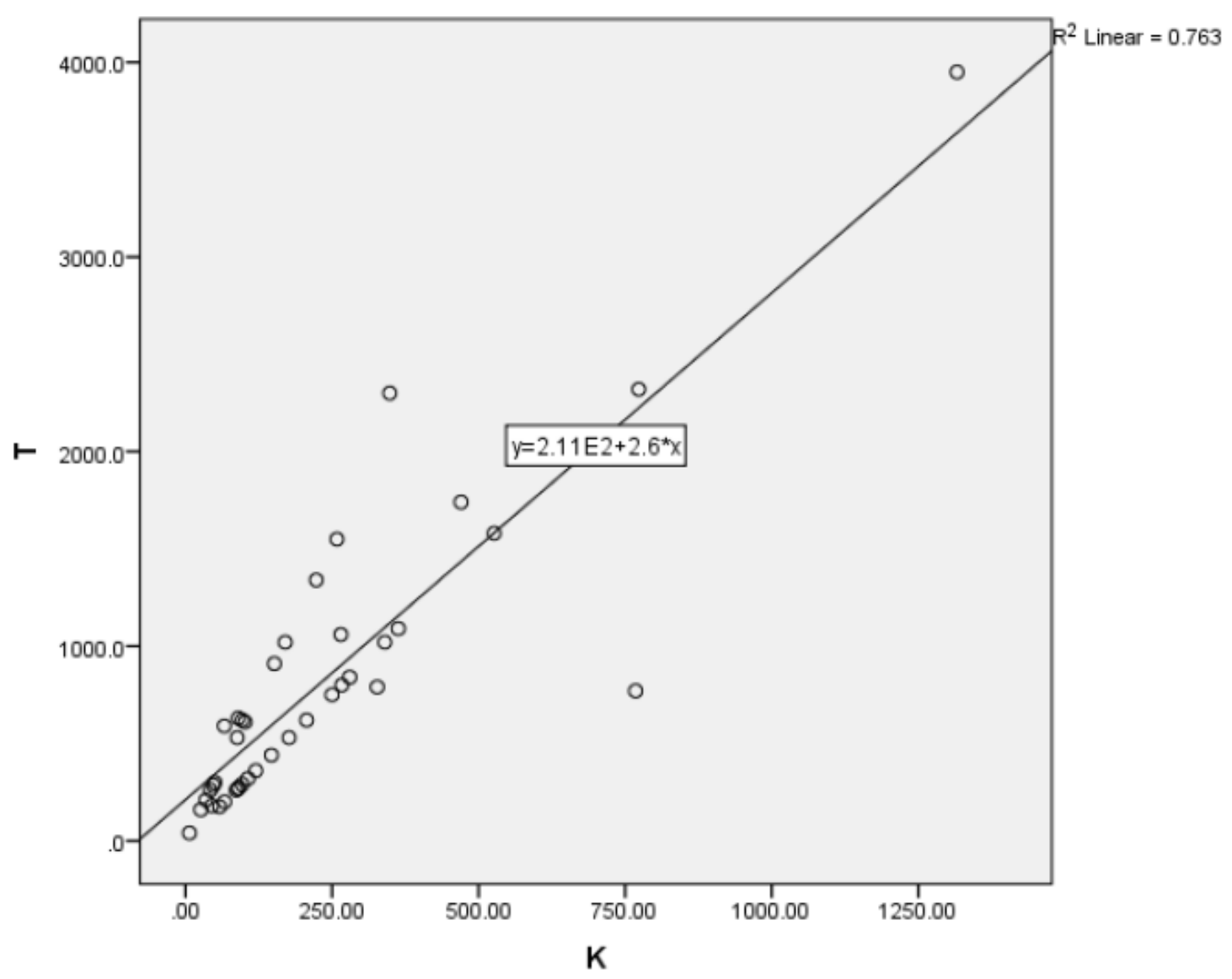

Figure 5e. A plot of specific capacity against hydraulic conductivity

\section{Conclusion}

Sokoto Basin Floodplains and Fadama lands have potentials for groundwater that is capable of sustaining both domestic and agricultural utilization within the communities of the Semi-arid region of northwestern Nigeria for a long period. Evaluated aquifer parameters revealed groundwater resources under both confined and semi- confined condition that is replenished through precipitation and recharged by rivers and vertical recharged through upward movement from sedimentary rocks below the alluvial aquifer. The shallow aquifers in the area are predominantly made up of alluvial sand with few being gravel which are characterized with good water storage and transmission ability. Statistical comparison between computed hydraulic characteristics of tube wells revealed that there is a good correlation between transmissivity, specific capacity and Yield showing the dependency of these properties on one another, however there is no good relationship between these parameters and storativity. The Fadama/floodplain areas of the Sokoto basin are categorized as Major Intermediate and Minor based on Hydrogeological conditions and groundwater level fluctuation.

\section{References}

[1] Swindell, K. Population and Agriculture in the Sokoto Rima of north-western Nigeria: A study of political intervention, adoption and change, 1800-1980. In: Cahiers d etudes africanes, (1986): vol. 26 no 101-102, pp 75-111.
[2] Takeshima, H. Adeoti, A. Okoli, S., Salau, S. Rhoe, V. Demand characteristics for small- scale private irrigation technologies: knowledge gap in Nigeria. Abuja IFPRI. (2010): (Working paper, no 0018)

[3] Anyadike, R. Seasonal and annual rainfall variations over Sudan. International journal of climatology, (1983): vol 13, pp 567-580.

[4] Hess, T., Steephene, W. and Marya, U. Rainfall trends in the North-eastern Arid zone of Sudan: Agric and forest met., (1995): 74: pp 87-97.

[5] Adams W.M., Traditional agriculture and water use in the Sokoto valley, Nigeria. The geographical journal (1986): 152(1): pp 30-43.

[6] Dabi D.D. and Anderson W.P. Water scarcity and Sustainable Agricultural Development in Draught prone Semi-arid zone of West Africa: In Demaree. G. Alexandre, J. and Dapper, M. Eds. Proceedings of international conference Tropical climatology meteorology and Hydrology, held in Brussels, Belgium, (1998): pp693-709.

[7] Tarhule, A. and Woo, M. Characteristics and use of Shallow wells in a Stream Fadama: Applied geography, (1997): vol: 17 no 1 pp 29-42.

[8] Ette, O.J., Okuolfu, C.A., Adi,e D.A., Igboro S.B., Alagbe, S.A. and Etteh, C.C. Application of environmental isotopes to assess the renewability of groundwater of Continental interclair aquifer of Sokoto Basin in northwestern Nigeria: Elsevier groundwater for sustainable development, (2017) : 4 pp 35-41.

[9] Adelana SMA, Olasehinde IP and Vrbka p A Quantitative estimation of groundwater recharge in part of the Sokoto basin, Nigeria; journal of environmental hydrology. (2006): vol 14 paper 5. pp $1-16$

[10] Davies, G. Geology in Sokoto State in Maps, Ibadan University press. (1982): 6-7.

[11] Kogbe, C.A. Geology of the southeastern (Sokoto) sector of the Iullemmeden basin, bulletin geology department Ahmadu Bello University,Zaria Nigeria. (1979): 2:1, pp 42-64.

[12] Udoh, R. K. Geographical regions of Nigeria, Heineman, London. (1970).

[13] Raeburn, C. and Tattam, C.M. A prelimininary note on the sedimentary rocks of Sokoto province. Niger. Geol. Surv Bull. (1930): 13 pp 57-60. 
[14] Jones B (1948) The sedimentary rocks of Sokoto province, Geological survey Nigeria bulletin 18: pp 1- 75 .

[15] Kogbe, C.A. Cretaceous and Tertiary of the Iullemmeden basin in Nigeria (West Africa): Cretaceous research. (1981): 2, 129-186, pp 30-186.

[16] Anderson, H.R. and Ogilbee, W. Aquifer in the Sokoto Basin, Geol. Survey water supply paper. (1973): 1757, USGS Report, $79 \mathrm{p}$

[17] Oteze, G.E. Recharge characteristics of Rima aquifers, Sokoto Basin, Water resources, (1989): 1 (2), pp 154-160.

[18] Bassey, J.O., Maduabuchi C, Onugba A, Verhagen BTH and Vrbka P. Preliminary results of Hydrogeological and isotopic research in the Rima River Basin, northwestern Nigeria, water resources. (1999) : 10 (1\&2), pp 31-37.

[19] Adelana SMA, Vrbka P, and Olasehinde PI Hydrochemical characteristics of groundwater in the Sokoto Basin, northwestern Nigeria, West Africa. Zentralblatt fur geologie und Palaontologie; Teit 1 Heft (2001) 3/4: 365-374; Stuttgart (Schweizerbart).

[20] Adelana SMA, Olasehinde PI, and Vrbka P, Groundwater recharge in the cretaceous and tertiary sediment aquifers of northwestern Nigeria, using Hydrochemical and isotopic techniques. In: E Bocanegra, D, Martinez and H. Massone (eds) Estimation of groundwater recharge. (2002) pp 49-72.

[21] Younger, P. L. Simple generalized methods for estimating aquifer Storage parameters. Quarterly journal of engineering geology: (1993): 26 pp 127-135.

[22] MacDonald, A.M., Bosor, H.C., Calow, R.C., Taylo,r R.G., Lapworth D.J., Maurice, L., Tucker, J. and ODochartaigh, B.E Groundwater resilience to climate change in Africa. British Geological Survey open report, (2011): OR/11/031.25P.

[23] Enokela, O.S. and Abua, C.A. The yield characteristics of of the shallow aquifers of River Katsina Ala floodplain in Nigeria: international journal of sciences. (2013): vol : 2,9 pp77-85.
[24] Abdullahi, A .S., Amin, A .S., Ahmad, D. and Umar, B., Characteristics of irrigation tube wells on major river floodplains in Bauchi state, Nigeria, Ambiente \& Agus- an interdisciplinary journal of applied science: (2014) vol. 9 no. 4 pp 602-609.

[25] Cooper H.H. and Jacob,C.E, A Generalized Graphical Method for Evaluating Formation Constants and Summarizing Well-field History. Trans-America geophysical Union. (1946): 27. pp 526-534.

[26] Georghe, A. Processing and Synthesis of Hydrogeological data Abacus press, Tumbridge Wells Kent. (1978): pp 122-136.

[27] Krasny, J. Classification of transmissivity magnitude and variation. Groundwaterjournal of Association of groundwater scientists and engineers. (1993).

[28] Hamidu, H., Abubakar, U., Abdulganiyu, Y., Usman, M.B. and Ibrahim, F.G. Groundwater resources evaluation of the Upper Bima Sandstone aquifer in Kaltungo area and environs, northeastern Nigeria: Zaria geographer, (2015) : vol. 22, no 1, pp 48-59.

[29] Brassington, R. Field hydrogeology, Geological society of London professional hand book series. John Wiley and Sons, (1988): 175p.

[30] Fauzie, M.J., Azwan, M.M.Z., Hasfalina, C.M. and Mohammed, T.A. Performance evaluation and characteristics of selected tube wells in the coastal alluvium aquifers of Selangor: pertanka journal of science and technology. (2014) : 22(1): pp 225-237.

[31] Uma, K .O. and Kehinde, M. O. Potentials of regolith aquifers in relation to water supplies to rural communities: A case study from parts of northern Nigeria, journal of mining and geology, (1994) : 30(1): pp 97-109.

[32] Chilton P.J. and Smith-Carington A.K. Characteristics of the weathered basement aquifer in Malawi in relation to rural water supplies: Challenges in African hydrology and water resources (proceedings in the Harare symposium, IAH Publ. (1984): no 144. Pp 57-72. 